\title{
INTRODUCTION
}

What's in a name--to be precise, in the name Marcus Garvey? A century after his birth, what should we know about him and the extraordinary movement that bears his name?

The name Garvey has come to define both a discrete social phenomenon, organized under the banner of the Universal Negro Improvement Association (UNIA) and African Communities League (ACL), and an era of black renaissance, in which Garveyism and the concept of black racial pride became synonymous. Before white America fell enraptured before the spell of what Claude McKay termed "the hot syncopated fascination of Harlem" in the Jazz Age, black America had already traversed the age of Garvey and the New Negro.' Garveyism as an ideological movement began in black Harlem's thirty or so square blocks in the spring of 1918 , and then burgeoned throughout the black worldnearly a thousand UNIA divisions were formed, and tens of thousands of members enrolled within the brief span of seven years. The reign of the Garvey movement, as Rev. Adam Clayton Powell, Sr., wrote, "awakened a race consciousness that made Harlem felt around the world."2

\section{Popular Hero}

Borne along on the tide of black popular culture, Garvey's memory has attained the status of a folk myth. While the

I. Claude McKay, A Long Way from Home (1937; reprint New York: Lee Furman, 1970), p. I50.

2. Adam Clayton Powell, Sr., Against the Tide: An Autobiography (New York: Richard R. Smith, 1938), p. 71. 
1987 centennial of Garvey's birth will be marked by formal ceremonies honoring his memory, on a more dynamic plane, Garvey is daily celebrated and re-created as a hero through the storytelling faculty of the black oral tradition.

As the embodiment of that oral tradition transmuted into musical performance, Jamaica's reggae music exhibits an amazing fixation with the memory of Garvey. Reevoking spiritual exile and the historic experience of black dispossession, the music presents a Garvey who speaks from the past directly to the present:

Marcus say, Marcus say, red for the blood that flowed like a river

Marcus say, Marcus say, green for the land, Africa

Marcus say, Marcus say, yellow for the gold that they stole

Marcus say, Marcus say, black for the people they looted from ...

\section{—“Rally Round," Steel Pulse}

In extending the legend of Garvey, the downtrodden have succeeded in rescuing his image from years of official neglect. In addition to carrying out this process of vindication, the music has succeeded in merging his name into an anthem of dispossession:

Marcus Garvey words come to pass

Marcus Garvey words come to pass

Can' get no food to eat

Can' get no money to spend

—“Marcus Garvey,” Burning Spear

In the transfiguration of Garvey in popular memory, historical time has been replaced with mythical timelessness. "Garvey soul yet young / Older than Garvey / Younger than Garvey," lyrically muses Burning Spear, the Jamaican reggae 
songwriter and performer, venerating the ongoing importance of Garvey.

In the course of this musical apotheosis, the mythic Garvey becomes the black race's prophet, as we hear in the exhortation calling people to account:

Marcus Garvey prophesy say, Oh yeah

Man a' go find him back against the wall, yeah

It a' go bitter ...

'Dis 'yah a' prophecy,

Hold 'dem, Marcus.

—“Right Time," Mighty Diamonds

If there is a moral in the music, it is that the memory of Garvey is a vital force-daily oral-musical performance has transformed the historic Garvey into a symbolic image that lives on in the popular imagination. Like the sacred African trickster-hero, who interprets the hidden to humans, the name Garvey serves to remind:

I'll never forget, no way

They sold Marcus Garvey for rice ...

So don't you forget, no way

Who you are and where you stand in the struggle

—"So Much Things to Say,"

Bob Marley

These lyrics are testimony to that fact that in the struggle for the ultimate regeneration of Africa, Garvey has continued to inspire succeeding generations. "While Mr. Garvey might not live to see his dream come true," prophesied one of his followers in 1924, "what he has said from the platform of Liberty Hall will be repeated in the years to come by unborn generations, and some day in the dark remote corners of 
Africa the Red, the Black and the Green will float.'3 This statement, with its figurative depiction of the liberation of Africa and the international influence of Garveyism in the struggle for its attainment, has proved to be an accurate prognosis of political transformation in Africa. "The question may start in America," Garvey had promised, speaking in Washington, D.C., "but [it] will not end there."4

\section{The Man and the Movement}

While Garvey's name has achieved legendary proportions, and his movement has had an ongoing international impact, Garvey as a mortal being was a man who embodied the contradictions of his age. He was seen by his own contemporaries in a plethora of ways, both positive and negative. "A little sawed-off and hammered down Black Man, with determination written all over his face, and an engaging smile that caught you and compelled you to listen to his story" was how the veteran black journalist John E. Bruce ("Bruce Grit") recalled his initial encounter with the young Jamaican in the spring of 1916. Encouraged by Booker T. Washington, Garvey had come to America hoping to gather support for a proposed school, to be built in Jamaica, patterned on the model of the famed Tuskegee Institute. By the time Garvey could get to the United States, however, Washington was dead. Garvey started with a nucleus of thirteen in a dingy Harlem lodge room. Within a few short years, he was catapulted to the front rank of black leadership, at the head of a social movement unprecedented in black history for its sheer size and scope. Writing in 1927, six months before Garvey was to be deported from America, Kelly Miller, the Afro-American educator and author, reflected upon the phenomenon:

Marcus Garvey came to the U.S. less than ten years ago, unheralded, unfriended, without acquaintance, relation-

3. Negro World (hereafter $N W$ ), 23 November 1924.

4. $N W, 26$ January 1924. 
ship, or means of livelihood. This Jamaican immigrant was thirty years old, partially educated, and roo per cent black. He possessed neither comeliness of appearance nor attractive physical personality. Judged by external appraisement, there was nothing to distinguish him from thousands of West Indian blacks who flock to our seaport cities. And yet this ungainly youth by sheer indomitability of will projected a propaganda and commanded a following, within the brief space of a decade, which made the whole nation mark him and write his speeches in their books. 5

In the world of the twenties, personalities quickly became notable and were fastened upon by admirers, detractors, and the merely curious. But even by the standards of the day, Garvey's rise from obscurity was spectacular. Speaking to an audience at Colón, Panama, in 1921, Garvey himself noted that "two years ago in New York nobody paid any attention to us. When I used to speak, even the policeman on the beat never noticed me."6

Garvey voiced the marvelous nature of his own rise when he asked an audience in I92I "how comes this New Negro? How comes this stunned awakening?" The ground had been prepared for him by such outspoken voices as those of Hubert H. Harrison, A. Philip Randolph, Chandler Owen, and W. A. Domingo. These and other stepladder oratorswho began speaking along Lenox Avenue with the arrival of warm weather in 1916 and whose number rapidly grew with each succeeding summer-were the persons who, along with Garvey, converted the black community of Harlem into a parliament of the people during the years of the Great War and after. The World War I era was the time of the

5. Kelly Miller, "After Marcus Garvey-What?" Contemporary Review I3I (April 1927):492.

6. $N W, 30$ July 1921.

7. NW, 18 June 1921. 
rise of "the ebony sages," as William H. Ferris termed the New Negro intelligentsia, who laid the foundation in those years for what would eventually come to be known as the Harlem Renaissance. Garveyism was fed in an environment where "in barber shops and basements, tea shops and railroad flats," Ferris revealed, "art and education, literature and the race question were discussed with an abandon that was truly Bohemian."8 By the middle of the decade, Ferris would go so far as to claim that "The New Negro is Garvey's own Child, whose mother is the UNIA."

When the UNIA was organized in Harlem in February 1918, its Jamaican leader merged not only with representatives of the New Negro, but with another minority: from the perspective of America's polyglot of ethnic groups, Garvey was simply one more immigrant voice. The Garvey phenomenon began amidst the multiple migrations of America, and it was not unusual to find Garvey issuing pronouncements of confraternity with the causes of various immigrant groups. ${ }^{10}$ "Just at that time," recalled Garvey, speaking in Liberty Hall in early 1920 about his start as a street orator in Harlem, "other races were engaged in seeing their cause through-the Jews through their Zionist movement and the Irish through their Irish movement-and I decided that, cost what it might, I would make this a favorable time to see the Negro's interest through."II

A notable feature of Garveyism as a political phenomenon was the staunch manner in which it accentuated the identity of interests among blacks all over the world. For Hodge Kirnon, this quality of internationalism essentially defined the New Negro mood. He observed:

The Old Negro press was nationalistic to the extreme, even at times manifesting antipathy and scorn for foreign

8. William $H$. Ferris, "The Negro Intellectual," $N W$, to June 1922.

9. Spokesman I, no. 4 (March 1925): 4.

10. New York Globe and Advertiser, 3 August 1920.

II. $N W, 6$ March 1920. 
born Negroes. One widely circulated paper went as far as to cast sarcasm and slur upon the dress, dialect, etc., of the West Indian Negro, and even advised their migration and deportation back to their native landsa people who are in every way law abiding, thrifty and industrious. The new publications have eliminated all of this narrow national sentimental stupidity. They have advanced above this. They have recognized the oneness of interests and the kindredship between all Negro peoples the world over. ${ }^{\mathrm{I} 2}$

A special feature by Michael Gold in the 22 August 1920 Sunday supplement of the New York World reported upon Garvey's meteoric ascent, and registered as well his immigrant status and the international nature of his message. The headlines accompanying the story made the following announcement:

The Moses of the Negro Race Has Come to New York and Heads a Universal Organization

Already Numbering 2,000,000

Which is About to Elect a High Potentate

and Dreams of Reviving the Glories of Ancient Ethiopia

Gold captured a defining characteristic of the Garvey phenomenon, namely, its rapid spread throughout the world, including sub-Saharan and southern Africa. Writing from Johannesburg, South Africa, a number of years later, Enock Mazilinko echoed the messianic vision of Garvey held by many in America when he wrote that "after all is said and done, Africans have the same confidence in Marcus Garvey which the Israelites had in Moses."'3 "Marcus Garvey is now admitted as a great African leader" concurred James Stehazu, a Cape Town Garveyite; indeed, Garvey was the embodiment

12. Hodge Kirnon, "The New Negro and His Will to Manhood and Achievement," Promoter, I (August 1920): 7.

13. $N W$, 9 February 1929. 
for tens of thousands of black South Africans in the postwar years of the myth of an Afro-American liberator. ${ }^{14}$ "Already his name is legend, from Harlem to Zanzibar," allowed the venerable Guardian of Boston when it appraised the significance of his life in 1940.15

But not everyone shared this concept of Garvey. Detractors labeled him a madman or the greatest confidence man of the age. "We may seriously ask, is not Marcus Garvey a paranoiac?" enquired the NAACP's Robert Bagnall in his 1923 article "The Madness of Marcus Garvey." 16 An earlier psychological assessment by W. E. B. Du Bois diagnosed Garvey as suffering from "very serious defects of temperament and training," and described him as "dictatorial, domineering, inordinately vain and very suspicious. 'T7 In the view of the organ of South Africa's African Political Organization, "the newly-created position of Provisional President of Africa [was] an empty honour which no man in the history of the world has ever held, and no sane man is likely to aspire after."'18

It was mainly as an embarrassment to his race, however, that Garvey was dismissed. "The Garvey Movement," reported Kelly Miller in 1927, "seemed to be absurd, grotesque, and bizarre."19 "If Gilbert and Sullivan were still collaborating," commented one African editorial writer, "what a splendid theme for a musical comic opera Garvey's pipe-dream would be." 20 W. E. B. Du Bois echoed this

14. NW, 16 July 1932.

I5. Boston Guardian, 18 May 1940.

I6. Robert Bagnall, "The Madness of Marcus Garvey," Messenger s (March 1923): 638. 60.

17. W. E. B. Du Bois, "Marcus Garvey," Crisis II (December I920): s8-

18. NW, 28 January 1922 (The African Political Organization was later renamed the African People's Organization). p. II.

19. Kelly Miller, “After Marcus Garvey-What?” Spokesman, May 1927,

20. Nigerian Pioneer, 17 December 1920. 
opinion when he described UNIA pageantry as like a "dressrehearsal of a new comic opera." ${ }^{21}$ A West Indian resident in Panama, writing in the April 1920 issue of the Crusader, offered an ironic commentary on what he took to have been Garvey's assumption of the grand title of African potentate: "Pardon me," the gentleman interposed, "but this sounds like the story of 'The Count of Monte Cristo' or the 'dream of Labaudy,' or worse still, 'Carnival,' as obtains in the city of Panama, where annually they elect 'Her Gracious Majesty, Queen of the Carnival,' and other high officials."22 White commentators were not excluded from this game of describing Garvey's conduct through the metaphor of entertainment. Borrowing from Eugene O'Neill's surrealistic play about the dramatic downfall of a self-styled black leader, Robert Morse Lovett referred to Garvey as "an Emperor Jones of Finance" to convey Garvey's financial ineptitude to highbrow readers of the New Republic.23

The wide variety of contemporary opinion about Garvey serves as a backdrop for his own eclectic descriptions of himself. He once announced that: "My garb is Scotch, my name is Irish, my blood is African, and my training is half American and half English, and I think that with that tradition I can take care of myself." 24 While Garvey told his audiences that his mind was "a complete machine," one "that thinks absolutely in the original," and, on another occasion, that his mind was "purely Negro," he also lamented that "the average Negro doesn't know much about the thought of the serious white man."2s His own ideology encompassed these two contradictory conceptions. For him, the thought

21. W. E. B . Du Bois, "Back to Africa," Century Magazine Ios, no. 4 (February 1923): 539.

22. Letter to the Editor, Crusader, April 1920, p. 28.

23. Robert Morse Lovett, “An Emperor Jones of Finance," New Republic, II July 1923.

24. Daily Gleaner, 19 January 1935.

25. Black Man (London) (hereafter $B M$ ) 3 (November 1938): 13; 4 (February 1939): 12; 3 (March 1938): 3. 
of the New Negro had to be a new thought, for it was incumbent upon the race to develop intellectual (as well as economic and political) independence as a precondition of survival in a world ruled by Darwinian ideas of the survival of the fittest. Nevertheless, the New Negro had to build this original thought on a strong foundation in the mainstream intellectual tradition, borrowing from that tradition while creating new racial imperatives. The present collection is a testimony to the diverse origins of Garvey's thought and to the ways in which he consciously embraced many of the dominant intellectual traditions of his age, reshaping them to the cause of pan-African regeneration.

\section{The ERA}

Garvey's career spanned the years of the climax of the Victorian era of empire and its denouement in the period of revolution and counterrevolution. Born in 1887, just after Queen Victoria's Golden Jubilee, Garvey grew up as a black colonial during the Edwardian era. He arrived at political maturity in the era of the nationalist revolution in Ireland and the October Revolution in Russia. He died on ro June 1940, the day that Fascist Italy declared war on the Allies and a month after Nazi Germany invaded France. He had predicted in 1937 that "the Negro's chance will come when the smoke from the fire and ashes of twentieth-century civilization has blown off." 26 His thought was of a piece with the dominant ideas of his tumultuous age, while at the same time offering a new response for blacks to the paradigm of white supremacy.

\section{LIFE AND LESSONS}

The present volume, Marcus Garpey: Life and Lessons, is a compendium of Garvey's eclectic philosophy. It is arranged in six sections. The first section, entitled "African Fundamentalism," contains the 1925 creed by that name-

26. $B M_{2}$ (December 1937): 3 . 
Garvey's attempt at a modern race catechism. The second section contains his abstract vision of the ideal state. Garvey's little-known serialized autobiography supplies the third section, and the fourth features Garvey's epic poem, The Tragedy of White Injustice. A series of dramatic dialogues from the Black Man makes up the fifth section. The sixth, and final, section consists of the lessons in leadership from Garvey's School of African Philosophy. The whole-garnered from materials created in the last fifteen years of Garvey's life-constitutes vintage Garvey and makes possible an enriched understanding of the popular allegiance that his ideas inspired.

\section{The Doctrine of Success}

Garvey's strong belief in the success ethic, a theme that forms a constant thread throughout his speeches and writings, is reflective of the popular culture of his times. Speaking in Halifax, Nova Scotia, in 1937, Garvey summed up for his audience the principle that he claimed life had taught him. "At my age I have learnt no better lesson than that which I am going to impart to you to make a man what he ought to be-a success in life. There are two classes of men in the world, those who succeed and those who do not succeed."27 Rejecting the class analysis being embraced by some of his black contemporaries, Garvey regularly illustrated his speeches with rags-to-riches stories, and offered examples from the fields of business and industry to his followers as models to emulate. In 1927 Joseph Lloyd, a Garveyite in Cuba, won a UNIA-sponsored "Why I am a Garveyite" contest with an essay on Garvey-inspired aspirations to become a black captain of industry or political leader. Garvey "has taught me," Lloyd wrote in the 6 January 1927 issue of the Negro World, "that I can be a Rockefeller, a Carnegie, a Henry Ford, a Lloyd George, or a Calvin Coolidge." Garvey himself had earlier asked readers of the Negro World in a 6 November 1926 editorial, "Why should not Africa give to the world its 
black Rockefeller, Carnegie, Schwab, and Henry Ford?" In the following year he spelled out the connection between such economic achievement and political power, informing his audience that

there is no force like success, and that is why the individual makes all efforts to surround himself throughout life with the evidence of it. As of the individual, so should it be of the race and nation. The glittering success of Rockefeller makes him a power in the American nation; the success of Henry Ford suggests him as an object of universal respect, but no one knows and cares about the bum or hobo who is Rockefeller's or Ford's neighbor. So, also, is the world attracted by the glittering success of races and nations, and pays absolutely no attention to the bum or hobo race that lingers by the wayside. ${ }^{28}$

Garvey's gospel of success was distinguished from more traditional versions of the doctrine because he merged personal success with racial uplift and established a link between these twin ideals and an overarching vision of African regeneration. In Garvey's perspective, success of the individual should serve the ends of race, and vice versa. "There are people who would not think of their success," Garvey insisted, "but for the inspiration they receive from the UNIA."29 Speaking in New York in 1924, Garvey claimed to have "already demonstrated our worth in helping others to climb the ladder of success." 30 Reciprocally, the UNIA relied for its own success on the organized support of individuals. "Help a Real Race Movement: The Way to Success Is Through Our Own Efforts" was the entreaty printed on the UNIA's contribution card in the early ig2os.

28. $N W, 29$ January 1927.

29. $B M_{3}$ (July 1938): 8 .

30. $N W$, i4 June 1924. 
Garvey offered a doctrine of collective self-help and racial independence through competitive economic development. "As a race we want the higher success that is within humanity's grasp," Garvey was quoted in the 21 February I93I "Garvey's Weekly Digest" column of the Negro World: "We must therefore reach out and get it. Don't expect others to pave the way for us towards it with a pathway of roses, go at what we want with a will and then we will be able to successfully out-do our rivals, because we will be expecting none to help us." Garvey also told his followers that the achievement of a higher class status among black people was the most direct route to obtaining opportunities and individual rights. "Be not deceived," he wrote, in the spirit of Andrew Carnegie, "wealth is strength, wealth is power, wealth is influence, wealth is justice, is liberty, is real human rights." ${ }^{\mathrm{I}}$

This imperative of success was tied to what a 21 March 1922 Negro World article termed "a universal business consciousness" among blacks in all parts of the world. By featuring the slogan "Africa, the Land of Opportunity," emblazoned on a banner draped across a picture of the African continent, the official stationery of Garvey's Black Star Line graphically illustrated this philosophy of racial vindication and uplift through capital investment and development.

\section{Self-Made Man}

Garvey himself was frequently cited in the pages of the Negro World as a prime example of a self-made man, one of those "who worked their way to the top of the ladder by the long, steady climb." 32 Garvey's interest in conductof-life literature and the persistent echoes of it heard in his speeches and writings reflect the impact that such classic success treatises as Booker T. Washington's $U_{p}$ from Slavery and Andrew Carnegie's Gospel of Wealth made upon

3I. $B M$ I (July 1935): 5 .

32. $N W, 23$ August 1924. 
him. These works were in turn part of an older genre dating back to Emersonian treatises on self-reliance, slave narratives of personal endurance and triumph such as Frederick Douglass's My Bondage and My Freedom, and Benjamin Franklin's colonial guide to practical behavior and economic success. Garvey's racial ideal was built upon the concept of success, and he saw himself as a black version of the Horatio Alger myth.

\section{New Thought}

Garvey's pragmatic philosophy, with its emphasis on self-mastery, determination, and willpower, also contained elements of New Thought, which emerged during the Gilded Age out of the allied branches of the mental healing phenomenon. With its emphasis on mind mastery, New Thought offered a set of metaphysical theories that proffered to its millions of adherents a system of mental hygiene to equip them for the journey along the road to success. In 1920 Hodge Kirnon commented on the pervasiveness of ideas from the teachings of Christian Science and the New Thought movements in the black community. "The Negro has been seized by this spirit," Kirnon declared, "he has taken a real change of attitude and conduct. So great has been the change," he continued, "that he has designated himself under the name of The New Negro." 33 Another member of the New Negro phalanx, William Bridges, also alluded to the subsistence of a link between the "spirit of radicalism and new thought." 34 Garvey was assessed by one of his closest colleagues in the leadership of the UNIA, Robert L. Poston, as "the man who is truly the apostle of new thought among Negroes." 35 Indeed, what was deemed a new racial philosophy was in fact Garvey's wholesale application of the dynamics of

33. "The New Negro and His Will to Manhood and Achievement," Promoter I (August 1920): 4.

34. Challenge 2, no. 5 (1919): 140.

35. $N W, 8$ September 1923. 
New Thought to the black condition. "I have come to you in Jamaica," Garvey announced on his tour of the Caribbean in spring 1921, "to give new thoughts to the eight hundred thousand black people in this-land." 36 Speaking before the UNIA's fourth international convention, he declared: "The Universal Negro Improvement Association is advancing a new theory and a new thought ...;" and in 1937 he stated that "to rise out of this racial chaos new thought must be injected into the race and it is this thought that the Universal Negro Improvement Association has been promulgating for more than twenty years." 37

Metaphysics and politics were explicitly linked in Garvey's mind. Turning to New Thought to explain the "African vision of nationalism and imperialism," Garvey advised that "the African at home must gather a new thought. He must not only be satisfied to be a worker but he must primarily be a figure."38 This New Thought philosophy permeated many UNIA functions and was a strong influence in the literature surrounding the movement. In 1930 the Black Cross Nurses of the Garvey Club of New York City held a medical demonstration at the facilities of the New York branch of the Field of New Thought on 94th Street. ${ }^{39}$ The Negro World regularly advertised books that showed New Thought influences, including I. E. Guinn's Twelve of the Leading Outlines of New Thought. $4 \circ$ Alonzo Potter Holly's popular book on blacks in sacred history, God and the Negro, was, according to Holly, inspired by Ella Wheeler Wilcox. Wilcox, whom Holly described as "an impassioned apostle of 'the New Thought,"' was in turn one of Garvey's favorite poets. ${ }^{4}$

36. Daily Gleaner, 4 April 1921.

37. NW, 9 August 1924; $B M 2$ (August 1937): 3.

38. $B M_{3}$ (July 1938): 5 .

39. $N W, 4$ October 1930.

40. NW, 27 September 1930.

4I. Alonzo Potter Holly, God and the Negro (Nashville: National Baptist Publishing Board, 1937), p. 14. 


\section{BOOSTERISM}

Besides its affinity with the gospel of success and the New Thought movement, Garveyism shared the strong emphasis on boosterism that pervaded the popular culture of the Progressive period. On 28 April 1921 Garvey informed an audience in Colón, Panama, that he admired "the white man's spirit for he boosts for race and nation." 42 A few months earlier he had written that "no sensible person objects to any man boasting, booming, and advertising the work or cause that he represents. The old adage still applies: ' $\mathrm{He}$ who in this world would rise/ Must fill his bills and advertise."'43 One of the Negro World's own advertisements read "If it is Success You Need in Business, Advertise in the Negro World"44 and advertisements heralding various pathways to success and selfpromotion regularly appeared in its pages under such titles as "Develop Your Power of Achievement," "How to Get Rich," "Key to Progress, Success, and How Attained," "Knowledge is Power: Make Your Life Yield its Greatest Good," and "Read This Book for Wealth and Health."

\section{VICTORIAN SENSIBILITY}

While Garvey's speeches and writings display the influence of popular success ideologies and a racial interpretation of international politics, they also reflect an adherence to a Victorian historical sensibility and literary taste. An admirer of the great and forceful men of history-statesmen, emperors, and conquerors (e.g., Alexander, Charlemagne, Hannibal, Napoleon, Genghis Khan)-Garvey called blacks to rise to a similar vision of political patriarchy and racial leadership. Likewise, while urging his readers and audiences to know and respect the works of black writers and artists, he consistently held up to blacks the work of minor

42. National Archives, RG 165, file 10218-418-18.

43. $N W$, 5 February rg2r.

44. $N W, 7$ February 1925 . 
and major white authors-Elbert Hubbard, William Ernest Henley, Robert Browning, Cervantes, Shakespeare-for inspiration and reference. By doing so, he upheld the tradition of schooling in "great works" common to the artisan class in the Victorian era. Indeed, Garvey's motto for the UNIA was quite likely a paraphrase of a line found in the poem of Alfred, Lord Tennyson, written for the occasion of Queen Victoria's opening of the Indian and Colonial Exhibition.
Britain's myriad voices call,
'Sons, be welded each and all,
Into one imperial whole,
One with Britain, heart and soul!
One life, one flag, one fleet, one Throne!

In Garvey's hands, the triumphal exhortation of the final line is paraphrased in the well-known UNIA motto, "One God, One Aim, One Destiny." Likewise, the name given by Garvey to the general assembly hall of the UNIA in Harlem, Liberty Hall, which became the cradle of the movement, is reminiscent of Oliver Goldsmith's ever-popular She Stoops to Conquer (1773). In the second act of the play, the residence Liberty Hall is defined as a haven from the outer world, a place of freedom of thought and action-"pray be under no constraint in this house," Mr. Hardcastle assures his guests; "this is Liberty Hall, gentlemen. You may do just as you please here."

\section{VANITY FAIR}

More deliberatively, Garvey's choice of the title for his epic poem, "The White Man's Game, His Vanity Fair" (later reprinted in pamphlet form under the title The Tragedy of White Injustice) reflects a similar penchant for alluding to great works of English literature. But just as he endowed the gospel of success with new racial meanings, so he converted common literary allusion to his own purposes, making it a medium of a new racial politics. The incorporation of "Vanity 
Fair" in the poem's title alludes to the infamous marketplace by that name in John Bunyan's Pilgrim's Progress (1678). While William Makepeace Thackeray used the name of Bunyan's town as a metaphor for the decadence of bourgeois society in London in his 1848 novel Vanity Fair, Garvey employed the name of the town in his 1927 poem to encapsulate its theme of white oppression and decadence. Just as Bunyan's work is a kind of sacred picaresque in which evil is pitted against good, so Garvey's poem is a chronicle of the atrocities committed against native peoples by white colonizers. In Bunyan's allegory, Christian, the protagonist, and Faithful, his traveling companion, are waylaid on their journey toward the Celestial City at Vanity Fair, a market town ruled by Beelzebub. In this hellish town, the streets are named after Britain, France, Italy, Spain, and Germany. "Knaves and rogues" and "thefts, murders, adulteries, false swearers" are met with on these thoroughfares, and vanities bought and sold. The two travelers are taken prisoner, tortured, and ridiculed. Faithful is tried in a court presided over by Judge Hategood - with a jury made up of Mr. Blind-man, Mr. Malice, Mr. Cruelty, and others-and sentenced to death. He is whipped, stoned, and finally burned at the stake, whereupon his spiritual body is released from his ashes and carried up into the heavens by a horse-drawn chariot - a metaphor of deliverance popularly preserved in Negro spirituals.

In referring to Vanity Fair in The Tragedy of White Injustice, Garvey sought an analogy between the persecution experienced by Bunyan's travelers at the hands of the immoral townspeople and that experienced by Africans, Native Americans, and aboriginal Australians at the hands of Europeans during imperial expansion.

\section{The Place Next to Hell}

Bunyan's work was popular in the nineteenth century as a moral guide for children, and Garvey would undoubtedly have been familiar with it since his youth. Bunyan's 1678 classic was laden with social and political criticism, as was 
Garvey's own epic poem of the 1920s. Bunyan wrote Pilgrim's Progress while imprisoned for religious dissent in the county jail at Bedford, England, and gave it an autobiographical premise by having the dreamer who narrates the story sleeping in "the gaol." A vocal Nonconformist who opposed the teachings of the Church of England, he was arrested while preaching and served two six-year sentences, from 1660 to 1672 , and another six-month sentence, in 1676 and 1677. Garvey wrote The Tragedy of White Injustice while imprisoned in Atlanta, where he was incarcerated in large measure for his militant racial stand, which diverged sharply from prevailing norms. In writing the poem, he translated, as Bunyan did, his excellent oratorical skills into written form and created a text intended to convert a popular audience to a new philosophy and new conduct.

Garvey's references to Bunyan's classic continued after his release from prison and his deportation to Jamaica in 1927. While campaigning for a seat in Jamaica's colonial legislature in October 1929, he was convicted of contempt of court for criticizing the judicial system on the island. He declared that many judges were influenced by bribes and suggested that some be impeached and imprisoned. The Jamaican Supreme Court did not look kindly upon such contumacy and sentenced him, as a result, to three months' imprisonment in the Spanish Town prison. The episodea major setback in Garvey's efforts to establish a political career-contributed to his subsequent decision to make a permanent move to England in the mid-1930s. Garvey referred to Jamaica in this period as "the place next to hell." 4 In a New Jamaican editorial he created a Bunyanesque dialogue between two Jamaicans who referred to the country as a "Land of Agony and Tears," which was "small, small in size and small in character," and where people who spoke their minds would be imprisoned. In Bunyan's work, the City of Destruction, where Christian was born, is described as "a populous place, but possessed with a very ill conditioned, 
and idle sort of People." Just as Bunyan's Christian leaves the City of Destruction to its brimstone, so Garvey's two imaginary Jamaicans recommend that the only way to remedy the evils they had witnessed was "by leaving the place and make it perish by itself." 46 Garvey echoed these themes in a May 1934 speech in which he denounced the hypocrisy of the country and announced his intention to publish a book about his journey through life, called, significantly, The Town Next to Hell. He told his audience that he had experienced a vision of "a night in hell" in a dream and that what he had seen was an authentic reflection of life under colonial rule in the Depression.

Garvey's promise to write an allegory on the subject of Jamaica was to some extent fulfilled; in July 1934 a poem written by him and entitled "A Night in Hell," was performed at a musical and poetic program at the Ward Theater in Kingston. Unfortunately, however, the text of the poem has not been preserved.

\section{Poetry and Oral Tradition}

Garvey's penchant for literary allusion and persuasion reflect his own belief that literature, particularly poetry, could be a powerful agent of personal uplift and a tool for teaching success. In the first lesson of the School of African Philosophy course for prospective UNIA leaders, he told his students to "always select the best poets for your inspirational urge." Writing a review of a poetry reading for the New Jamaican, he reminded his readers that "many a man has gotten the inspiration of his career from Poetry." $47 \mathrm{He}$ went on to describe the beneficial effects of poetry readings, stating that the listener "is able to enter into the spirit of the Poets who write the language of their souls," while the poets themselves, in creating poetry, are forced to contemplate their

46. New Jamaican, 4 September 1933.

47. New Jamaican, 26 January 1933. 
lives deeply, "and when they start to think poetic they may realize that after all life is not only an 'empty dream."' In this perspective, poetry grants those receptive to it inspiration, and inspiration leads to ideation and action.

Garvey's writings and speeches also show the powerful legacy of his schooling in Victorian moral exhortation through elocution, as well as his genius in integrating the practice of declamation with West Indian and Afro-American traditions of verbal performance. In the dialogues created for the Black Man in the mid-1930s, Garvey adapted the Platonic form of didactic conversation between teacher and student, with its progression of statement, discussion, and debate, leading to the transfer and growth of knowledge. The dialogues also demonstrate his special sensitivity to communicating with an audience steeped in an oral tradition. By translating the written word into a script of two voices that was to be read as if it were spoken, Garvey created a kind of call-and-response conversational pattern designed both to uplift and to instruct. In any event, Garvey loved an argument.

\section{Dialogues}

Garvey's experimentation with the dialogue form occurred during the period of its revival following the publication of Goldsworthy Lowes Dickinson's After Two Thousand rears: A Dialogue between Plato and a Modern Young Man (1930). Dickinson had earlier received wide scholarly acclaim for his brilliant series of dialogues in the Socratic tradition, the most famous of which was A Modern Symposium (190s), a treatise that was in some ways a manual of modern politics. In 1931, while Garvey was visiting England, Dickinson broadcast a series of popular radio courses on the dialogues of Plato which were expanded for publication in Plato and His Dialogues (1931).

During the period of Dickinson's success, the prominent black journalist Joel A. Rogers also popularized the dialogue form as a medium for the discussion of the race question. 
His From "Superman" to Man (1919) contained debates on race issues presented under the guise of a series of conversations between the erudite Dixon, a black porter, and various passengers who traveled aboard his train, particularly a southern Senator with well-entrenched beliefs in white supremacy. What emerged was a scathing critique of the doctrine of white racial superiority. Rogers's work was widely read and acclaimed, both for its content and for what a reviewer for the Boston Transcript called its "fascinating style and convincing logic."48

\section{ReLigious INFLUENCES}

It might be said that Garvey's greatest achievement was his ability to change the consciousness of black people. Upon his return to New York following a month-long speaking tour of the Midwest in 1920, he likened his movement's impact upon popular consciousness to a religious conversion: "The masses of the race absorb the doctrines of the UNIA with the same eagerness with which the masses in the days of the supremacy of imperial Rome accepted Christianity. The people seem to regard the movement in the light of a new religion." 49 Garvey aimed to organize the instruction of black children according to the new "religion." He stated in a 27 June 1931 Negro World editorial that "the white race has a system, a method, a code of ethics laid down for the white child to go by, a philosophy, a set creed to guide its life," and that black children needed a similar code.

\section{African Fundamentalism}

"African Fundamentalism" was Garvey's quasi-religious manifesto of black racial pride and unity. It attained canonical status within a short time after it was first published as

48. Joel A. Rogers, From "Superman" to Man sth ed., 1968; reprint, Helga M. Rogers, 1982.

49. $N W, 16$ October 1920. 
a front-page editorial in the Negro World of 6 June ra2s. Written, like The Tragedy of White Injustice, while Garvey was confined in the Atlanta penitentiary, the essay proclaims ideological independence from white theories of history, makes concomitant claims of racial superiority, and articulates major themes that recur throughout Garvey's other writings and speeches. Chief among these are the ideas of racial selfconfidence, self-development, and success; international black allegiance and solidarity; and the importance of acquiring a knowledge of ancient black history.

Garvey's use of the term fundamentalism in the title reflects this stress on the need for regaining a proud sense of selfhood by setting aside modern racist labels of inferiority and reviving the basic, fundamental beliefs in black aptitude and greatness that he saw exemplified in ancient African civilization. At the same time, the term resonated with Garvey's long-standing preoccupation with development of an original "Negro idealism." This notion was essentially grounded in religion. "I don't think that anyone who gets up to attack religion will get the sympathy of this house," Garvey declared in a speech in 1929, "for the Universal Negro Improvement Association is fundamentally a religious institution."so

"African Fundamentalism" was written at the peak of the fundamentalist revival that swept American following World War I. The revival was expressed both as a theological doctrine and as a conservative neopolitical movement. While the concerns of Christian fundamentalists focused on a sociocultural return to a set of principles untainted by modern rationalism and secularism, and while Populist fundamentalists called for the maintenance of an older agrarian order that would belie the impact of industrialization and urbanization-so Garvey's call heralded a recognition of the achievements of Africans in the past and a return to the principles of black dignity and self-rule, principles that had been denigrated under the impact of modern racial oppression,

so. Blackman (Kingston), 3I August 1929. 
slavery, and imperial colonization.

As in his sardonic use of the phrase "Vanity Fair," Garvey's choice of the word fundamentalism reflects an intuitive understanding of the types of associations people would apply to his use of the term. He employs these associations in the context of the essay itself, wherein his references to monkeys, caves, and the process of evolution inevitably call to mind the opposing ideas of social Darwinism and the fundamentalist movement. The conflict between these two philosophies peaked symbolically in the Scopes trial, which got under way during the same summer "African Fundamentalism" was written. The trial, which was held in Dayton, Tennessee, in July 1925, pitted prominent attorneys William Jennings Bryan and Clarence Darrow against one another in a much-publicized courtroom battle. At issue was the acceptance of the theory of evolution and its place in the American school curriculum. Bryan argued for the creationist viewpoint (a fundamentalist perspective associated with the agrarian and southern sections of the United States and with the lower classes), while Darrow represented the modern, humanist viewpoint (a secular perspective associated with the urban and industrial areas of the North, with the growth of the social sciences, and with the educated middle classes). Bryan's side in the conflict prevailed, and teacher John T. Scopes was found guilty of breaking a law, passed by the Tennessee legislature in March 1925, prohibiting the teaching of any doctrine denying the divine creation of mankind as taught from a literal interpretation of the Bible.

In his essay, Garvey played on the social Darwinist issues that were publicly highlighted by the Scopes trial and gave them an ironic twist. He adopted elements of the evolutionary theory of the secularists and of the strong nativist strain of the fundamentalists and utilized them both as premises to support his own counterargument. He presented blacks in northern Africa as representatives of a higher form of life and culture than their white counterparts in Europe. He thus reversed the popular contemporary claims of white eugenicists, who applied evolutionary theory to the social 
milieu, associating people of African heritage with the slow development of the apes and offering their results as "proof" of white racial superiority.

Similar reversals of white-dictated beliefs and standards were reflected in Garvey's fervent praise for the compelling beauty of black skin and African features; in his championing of the worship of black images of the Virgin Mary, God, and Jesus Christ in the place of white conceptions of the deity; and in his call for a recognition of the heroic accomplishments of black people, such as Crispus Attucks and Sojourner Truth, whose martyrdom, selflessness, and rebelliousness qualified them for respect equal to that accorded white saints like Joan of Arc.

\section{Classical Influences and the Ideal State}

Much of Garvey's theory of education - with its emphasis on self-mastery and self-culture as precursors to good race leadership - can be traced to the classical model of education, where the training of the child is the basis of virtue, and virtue in turn is the necessary requirement of statesmanship. "Governing the Ideal State," written by Garvey in Atlanta Federal Penitentiary in 1925, manifests the influence of classical philosophy on Garvey's thought and on his view of contemporary political events. The essay stands also as a propagandistic exercise in self-vindication in the wake of Garvey's recent conviction on fraud charges. It offers an indictment of the behavior of UNIA leaders and staff members whose misconduct Garvey felt had led to his imprisonment. It is also a scathing comment on the American political system at large and on the widespread corruption among government officials and leaders in the era of the Teapot Dome scandal.

Garvey enjoyed using classical allusions to convey to his audiences the concept of greatness and nobility. In his 1914 pamphlet $A$ Talk with Afro-West Indians, he urged his readers to "arise, take on the toga of race pride, and throw off the brand of ignominy which has kept you back for so many centuries." Nearly two decades later he told readers that "the 
mind of Cicero" was not "purely Roman, neither were the minds of Socrates and Plato purely Greek." He went on to characterize these classical figures as members of an elite company of noble characters, "the Empire of whose minds extended around the world.' "xi The title of his 1927 Poetic Meditations of Marcus Garvey parallels the title of the work of the "philosopher-emperor" of Rome, The Meditations of the Emperor Marcus Aurelius Antoninus (121-180). Like the work of Marcus Aurelius, Garvey's meditations included a fascination with the themes of conduct and the moral tenets of Stoicism and Platonism.

In fact, Garvey subsequently described his "Governing the Ideal State" as an abstract exercise to be likened to "Plato's Republic and Utopia.'\$2 And like Plato and the Greeks, Garvey shared a strong belief, though he applied it to Africa of antiquity, in the notion of historical decline from a golden age. Garvey believed civilizations were subject to an inevitable cyclical process of degeneration and regeneration. In one of his earliest essays, entitled "The British West Indies in the Mirror of Civilization" published in the October 1913 issue of the African Times and Orient Review, he held up the prospect of a future historical role for West Indian blacks in relation to Africa on the premise of this cyclical view. "I would point my critical friends to history and its lessons," he advised, then proceeded to draw what was to be one of his favorite historical parallels: "Would Caesar have believed that the country he was invading in 55 B.c. would be the seat of the greatest Empire of the World? Had it been suggested to him would he not have laughed at it as a huge joke? Yet it has come true." 53 The essay is important as an early example of the equation, in Garvey's mind, of history with empire building and decline.

In "Governing the Ideal State," he announced the failure

51. "An Apostrophe to Miss Nancy Cunard," handbill, 28 July 1932.

52. Daily Gleaner, 2I January 1933.

53. Marcus Garvey, "The British West Indies in the Mirror of Civilization," African Times and Orient Review (October 1913): 160. 
of modern systems of government and called for a return to the concept of the archaic state, ruled over by an "absolute authority," or what Aristotle termed an absolute kingship. The fact that Garvey was well versed in Aristotle is highlighted by his request to his wife, shortly after the beginning of his imprisonment, to send him a copy of A. E. Taylor's Aristotle (1919), a standard commentary. In his essay, Garvey rejected democracy in favor of a system of monarchy or oligarchy similar to the one presented in Aristotle's Politics, the rule of "one best man," along with an administrative aristocracy of virtuous citizens. As was the case in Aristotle's utopiawhere those individuals with a disproportionate number of friends would be ostracized from society, while an individual demonstrating disproportionate virtue should be embraced and given supreme authority-in Garvey's ideal state the virtuous ruler would have no close associations other than with his family and, free from the corrupting influences that companionship might bring, would devote full attention to the responsibilities of state.

\section{Plato's LAWS}

Garvey borrowed the concept that the key function of law is the maintenance of authority not only from Aristotle, but from Plato, whose Republic and Laws presented a vision of an ideal state in which virtuous behavior is encouraged through education, while conduct deemed corrupt is punished according to a harsh system of penalties. Plato's penal code was in turn partially derived from the Hammurabic code that preceded it. The crimes of embezzlement and treason to the state through political factionalization, which Garvey suggested should be punishable by death, were also crimes meriting capital punishment in Plato's ideal state (Laws, 9.856) (however, Garvey's call for stoning as the means of administering the death penalty is more likely derived from biblical descriptions than from Plato). Plato recommended that all public officials be subject to an audit and, should the audit reveal unjust self-aggrandizement, "be branded with 
public disgrace for their yielding to corruption" (Laws, 6.76I762). Similarly, Plato wrote that "the servants of the nation are to render their services without any taking of presents" and, if they should disobey, be convicted and "die without ceremony" (Laws, I2.955). If, however, leaders passed the state audit and were shown to have discharged their offices honorably, they should, as Garvey's virtuous leader would, be pronounced worthy of distinction and respect throughout the rest of their lives and be given an elaborate public funeral at their deaths (Laws, 12.946-947). Just as Garvey suggested that a child who identified a father's crime should be spared the penalty of death, so Plato suggested that children who "forsake their father's corrupt ways, shall have an honourable name and good report, as those that have done well and manfully in leaving evil for good" (Laws, 9.85s).

Garvey's inclusion of kinship and property relations in consideration of the organization of his ideal state also mirrored the teachings of the Greek philosophers. He borrowed from Plato, who saw the state evolving from the family into a more communal relation and who granted free women some role in public life, in "universal education," and in the administration of the state. Garvey also borrowed from Aristotle, who, more than Plato, preserved the notion of the private household and the subordination of women as an integral part of his ideal state. Garvey centered the private life of his ideal ruler in a nuclear family and made the wife of the ruler a kind of chamberlain accountable for her husband's financial dealings. Both Aristotle and Plato based their ideal states on monogamous marriage and patriarchy, in which the household of a citizen was compared to the larger hierarchy of the state, with a wife subject to her husband as a subject is subordinate to a ruler. Garvey echoed this model in his essay, wherein the wives of leaders are deemed "responsible for their domestic households," regulated by law in the keeping of their husbands' private and public accounts, and subject to capital punishment along with their husbands for financial crimes committed during their husbands' tenure in office. Garvey's recommendation that both the wife and 
husband should be disgraced and put to death in cases of corruption in office mirrors not only the family relations of the Greek state but archaic Mesopotamian codes governing debt slavery, in which the wives or children of a male debtor could be enslaved or put to death in payment for his financial failures.

\section{The Ideal State and the UNIA}

"Governing the Ideal State" emerges as an essay in selfvindication and wish fulfillment and draws thinly disguised parallels between Garvey's vision of the ideal state and his desires for the correct operation of the UNIA. Just as the philosopher-ruler is the central theme of Plato's Republic, so is Garvey the focus of the essay. Garvey's character might also be adduced from the authoritarian type of society he proposes-an exercise that would be consistent with Plato's attempt to sketch the four types of character corresponding to the four types of society depicted in book 8 of the Republic.

Written from prison, at a period in his life that called for reflection about the course of his career and the factionalization and corruption that had overtaken the movement, Garvey's essay takes on an autobiographical quality, with significant psychohistorical connotations. Garvey clearly identified with the extreme authoritarianism of the supreme leader who appoints subordinate officials and exercises absolute authority over them. Just as Garvey impeached or expelled UNIA officers who disagreed with his policies or digressed from his vision of the organization's goals (often publicly disgracing them in the process), so Garvey's Spartan utopia would ensure strict accountability, as well as define the boundaries of conduct for subordinates. The role of the president's wife as his personal accountant in the ideal state closely parallels that of Amy Jacques Garvey as business manager at the UNIA headquarters as well as overseer of her husband'sthe president general's-personal accounts.

Garvey suggests, through his philosophical musing on the austerity of the ideal state, his own, as well as his wife's, 
exculpation by sketching draconian consequences for fraud and mismanagement. At the same time, Garvey's call for the disgrace of public officials who do not correctly perform their duties reflects a desire for retribution and revenge against fellow UNIA officers and staff members, many of whom he felt had deceived him and whom he charged with graft. Similarly, the call for clemency toward a family member who defied and reported corruption acknowledged Garvey's feelings toward those who remained loyal to him and who had testified in his defense during the mail fraud trial, offering evidence against the "disloyal" actions of others. The recommendations that the president of the ideal state be freed from pecuniary obligations are natural wishes from a man whose struggles to gain world renown as the head of a movement were always compromised by debt and material need. In addition, Garvey's description of the absolute leader as a man without friends is also a poignant reflection of his own, perhaps deliberate, isolation from close companionship, a theme that reappears in his advice to prospective UNIA leaders in his lessons for the School of African Philosophy.

\section{Political Corruption}

On a more overt level, "Governing the Ideal State" is a critique of the widespread corruption evidenced on the local, state, and federal levels of government in the rozos. Garvey was fond of noting that prison mates in Atlanta included former politicians, including Gov. Warren McCray of Indiana, who was convicted of embezzlement, forgery, and mail fraud in 1924; and Mayor Roswell Johnson of Gary, Indiana, who was imprisoned in Atlanta in April ro2s for participation in a liquor conspiracy ring during Prohibition. On a federal level, the nation was rocked in the early 1920 s by Senate investigations into irregularities committed by officials associated with the Harding administration, including the Teapot Dome oil reserve scandal of 1922-1923, which led to the eventual prosecution and conviction of government officials on bribery and conspiracy charges and to the inves- 
tigation and prosecution of former attorney general Harry $M$. Daugherty in 1924-1927, which revealed his close alliance with organized crime and frequent abuse of civil liberties through the power of his office. The irony of such malfeasance arising from within the institution of government that condemned him was not lost upon Garvey.

\section{Racial EdUcation}

Ethical and cultural instruction-the basis of virtue in Aristotle's ideal state-was one of the basic goals of the UNIA from its inception. Garvey believed in offering instruction both popularly and institutionally, with the dual goals of reaching a wide audience and of establishing educational facilities. The soapbox oratory, mass meetings, and large conventions that characterized the Garvey movement were all directed at instructing and organizing a large mass of people. Similarly, the dramatic performances, elocution contests, debates, and concerts that UNIA members participated in were forms not only of fund-raising and socializing, but of racial education as well. When Garvey purchased Edelweiss Park in Kingston, Jamaica, as a meeting center for the black community in the early 1930s, he continued the practices established in New York and throughout the local UNIA divisions-practices based on the nineteenth-century tradition of the Chautauqua circuit, where people would gather locally for popular education and enrichment combined with entertainment, often outdoors or beneath a tent. He advertised Edelweiss Park as a "great educational centre" and a "centre of people of intellect" in the pages of the New Jamaican.54

Garvey's interest in founding educational facilities was also a lifelong one. He attended courses at Birkbeck College in England before he founded the UNIA in 1914, and one of the new organization's earliest goals was the creation of an industrial training institute for blacks in Jamaica based on the Tuskegee model. Well before the turn of the century, 
the practical education in skilled crafts that industrial training offered had become one of the popular paths for artisans in their quest for self-culture. The 26 March rois Jamaican Daily Chronicle reported that Garvey listed the establishment of "educational and industrial colleges for the further education and culture of our boys and girls" as among the several benevolent goals of the UNIA. Garyey received support in this goal from Booker T. Washington, who, on 17 September 1914, wrote to invite the UNIA leader to "come to Tuskegee and see for yourself what we are striving to do," and promised again in April riss to help Garvey achieve his local aims.

Garvey's interest in education based on the principles of self-culture persisted after Washington's death in November I9Is and the relocation of the headquarters of the movement in the United States in 1916. UNIA meetings and programs continued to foster the ideal of self-improvement, and as the association grew, auxiliaries were created with their own educational standards for membership. These standards included examinations in the geography of Africa, mathematics, reading, writing, and other subjects for commissioned officers in the uniformed Universal African Legion; first aid and nutrition classes for the members of the Black Cross Nurses; automobile repair and operation instruction for the Universal African Motor Corps; and a curriculum of elementary courses, including instruction in black history, economics, and etiquette, for members of the Juvenile Divisions. In some areas, local Black Cross Nurse auxiliaries also contracted with community hospitals and clinics to provide members with more advanced practical training in nursing and maternity care.

In February 1918 Garvey invited Columbia University president Nicholas Murray Butler to address the members of the UNIA on the topic of "Education and What It Means," and in April of the same year he and the other officers appealed to Butler to contribute toward the purchase of a $\$ 200,000$ building in Harlem for an organization headquarters, which they hoped would "be the source from which 
we will train and educate our people to those essentials that will make them a more cultured and better race.'’s

\section{BOOKER 'T. WASHINGTON UNIVERSITY}

At the 1922 UNIA convention, Garvey announced the proposed opening of the Booker T. Washington University, which would be used to train leaders of the UNIA from around the world. The university, located on the same site as the UNIA-operated Phyllis Wheatley Hotel (3-13 West 136th Street, New York, a building rented by the UNIA), was designed to train officers for UNIA civil service positions in accordance with article 31 of the 1922 UNIA Constitution and Book of Laws. A convention committee on labor and industry offered a resolution that a course in agriculture and commerce also be provided at the university, enabling the UNIA to send experts on the subject into the field as advisers.

\section{LIBERTY UNIVERSITY}

While the operation of Booker T. Washington University was short-lived, in September 1926 the UNIA celebrated the opening of the newly acquired Smallwood-Corey Industrial Institute. Located in Claremont, Virginia, the school property included several buildings and sixty-six acres of land along the St. James River. A coeducational school, it was operated by a Hampton Institute graduate with a faculty of nine when it was purchased by the UNIA and renamed Liberty University. Amy Jacques Garvey referred to Liberty University in her memoirs as "a practical High School, ${ }^{\prime 6}$ and young UNIA members became students there beginning with the fall session in 1926. Advertisements for the university appeared in the Negro World, informing readers that the school had opened for the fall term on September is and that "every division or chapter should grant a scholarship to a deserving

55. Garvey Papers, I: 238.

56. Amy Jacques Garvey, Garvey and Garveyism (Kingston, 1963), p. I64. 
boy or girl and enable them to secure a liberal education.' 37 Optimistic officers announced the establishment of the school as the first in a chain of academies to be founded by the association. The school experienced great financial difficulties and, after struggling through three years of poverty, was closed in October 1929.58

Garvey was imprisoned in Atlanta when the UNIA acquired Liberty University, and he was never able to see the school in operation. During his incarceration he continued his personal dedication to self-education, ordering books and newspapers, and in October 1927 he contacted representatives of the Columbia University Home Study Department for information about their mail-order courses in philosophy and poetry. After his release and return to Jamaica, he used the editorial pages of the Blackman and New Jamaican for instruction in racial uplift. He began publishing the Black Man magazine in Kingston in 1933, and when he relocated the headquarters of the movement to London in 1935, he also transferred the publication of the monthly magazine. In March 1936 he described the London journal as "a kind of universal University to educate those who want to be educated in our school of thought." 99

\section{School of African Philosophy}

Garvey's long-standing interest in establishing a school to train individuals in his racial philosophy was realized a decade after his deportation from the United States, when he launched the School of African Philosophy in Toronto. Garvey reported to the readers of the December 1937 Black Man:

The School of African Philosophy has come into existence after twenty-three years of the Association's life for

57. $N W, 28$ August 1926 and 26 November 1927.

58. NW, i2 October 1929.

59. $B M$ I (March I936): 3 . 
the purpose of preparing and directing the leaders who are to create and maintain the great institution that has been founded and carried on during a time of intensified propaganda work. The philosophy of the school embodies the most exhaustive outlines of the manner in which the Negro should be trained to project a civilization of his own and to maintain it. 60

The first session of the school was held in September 1937, following the second regional conference of the American and Canadian branches of the UNIA in August. Garvey served as principal of the school and led the classes, which met daily, in day and evening sessions, from I to 23 September. Entrance was restricted to individuals with a high school education. Eleven students enrolled in the session, including four women and seven men, all from the northern or eastern United States or Canada. Ten of them passed the final examination and received appointments as UNIA regional commissioners.

Garvey described the course in African philosophy as including "a range of over forty-two subjects" and announced that an extensive correspondence course had been drawn up, open "only to Negroes." The course was available through mail order from UNIA headquarters at 2 Beaumont Crescent, West Kensington, London, for a fee of twenty-five dollars. According to a press release issued by Garvey from his London headquarters, the course "guarantees to prepare each man and woman for a useful career and sure success and prosperity."6I

\section{The Lessons and The Gospel of Success}

Garvey's course in African philosophy displays a strong affinity with the how-to lessons of New Thought therapeutics,

60. $B M 2$ (December 1937): 4.

6I. "Garvey Opens New School of African Ideals," Richmond Planet, 5 March 1938. 
exemplified in the titles of such well-known New Thought treatises as W. W. Atkinson's The Secret of Success: $A$ Course in Nine Lessons (1908), Elizabeth Towne's Lessons in Living (1910), Fenwicke L. Holmes's Being and Becoming: Lessons in Science of Mind (1920), Nona L. Brooks's Short Lessons in Divine Science (1928), and Brown Landone's The ABC of Truth: Fifty-fipe Lessons for Beginnings in New Thought Study (1926). Garvey's course in racial leadership could be justly described as a black version of New Thought, offering a similar system of practical metaphysics geared to achieving mental emancipation and personal success.

Garvey may also have been influenced by the phenomenal success of Dale Carnegie's How to Win Friends and Influence People, which was first published in November 1936. By the time that Garvey started the course in African philosophy, over half a million copies of Carnegie's treatise had been sold, making it the national best-seller for the preceding five months. The Carnegie Institute in New York, where Carnegie conducted courses for people who hoped to become leaders in the business and professional world, may well have served as a model for Garvey's own school for UNIA leaders. Garvey and Carnegie both emphasized the need to arouse enthusiasm in order to assume leadership and earn power and recognition. Both preached a gospel of self-improvement and practical study of a set of success-oriented principles. Both used examples of great leaders and businessmen, citing how many of the same favorites- Theodore Roosevelt, Thomas Edison, John Wanamaker, John D. Rockefeller, Benjamin Disraeli, Edward VIII, and P. T. Barnum-had succeeded, stressing the principle of hard work. Both shared the common phraseology of success, including a penchant for the terms fundamental, self-improvement, and self-education. Both taught their lessons in order to change behavior, practicing the dictum of Herbert Spencer that Carnegie quoted in his 1936 introduction: "The great aim of education, is not knowledge but action." 62 Carnegie told his readers that

62. Dale Carnegie, How to Win Friends and Influence People (1936; reprint, New York: Simon and Schuster, 1964), p. 17. 
he was "talking about a new way of life" 33 while Garvey termed his lessons in African philosophy a "New Way to Education." 14 Both included tricksterlike advice on how to manipulate and persuade others. While Carnegie saw human relations as a kind of game of disarming potential enemies, in which an appearance of sincerity was key, Garvey gave lessons in what he called "diplomacy," or the artful deception of opponents. While Carnegie noted the power of a "captivating smile"6s in swaying people, Garvey advised his students to "win the world to you with a smile." ${ }^{36} \mathrm{He}$ echoed the title of Carnegie's book when he told his students to "Never approach anybody that you want to get anything out of or any good results from, in an offensive manner; to the contrary, win them with the perfect smile ... the idea is to make friends and to get results."67 Both men were interested in the organizing power of what Carnegie called showmanship and style; and Carnegie illustrated the concept by the example of Garvey's hero, Napoleon, who stimulated a feeling of importance among his followers by awarding them exalted titles he had himself created. Each of the graduates of the first class of Garvey's School of African Philosophy received a new title and appointment as a regional commissioner for the UNIA.

\section{ETHIOPIANISM}

Some of the ideas Garvey presents in the lessons from the School of African Philosophy are also similar to thought current in the Ethiopianist movement in Jamaica of the same period and to his own "African Fundamentalism." The idea of finding antecedents of Egyptian civilization in ancient Ethiopian culture-including the view that Ethiopians were

63. Carnegie, How to Win Friends, p. 37.

64. $B M_{4}$ (February 1939): 6.

65. Carnegie, How to Win Friends, p. 67.

66. lesson 18.

67. lesson 9. 
the architects of the pyramids and of the Sphinx-is one such common link. The "leprosy" theory of Caucasian racial origin that Garvey presents in lesson $\mathrm{I} 2$ was also an ideological strain of Ethiopianism. By 1937, when Garvey taught the first course in African philosophy, the identification of the white man as a leper had become a part of emergent Rastafarian doctrine in Jamaica, which drew upon the older Ethiopianist reference to Numbers 12:10, wherin Miriam becomes leprous-"white as snow." Garvey taught that Adam and Eve and their progeny were black and that Cain was the first leper, stricken white as a punishment by God for the murder of his brother, Abel. Garvey differed from Ethiopianist teachings when he claimed that Tutankhamen and other Egyptians were blacks who enslaved the Hebrews. For many adherents of Ethiopianism, people of African descent-enslaved and subjected to dispersion from their ancestral African homeland-were strongly identified with the Jews; indeed, some believed that black people were actual descendants of the Jews who had experienced slavery. "The Negro must be [the] original Children of the Sun, of IsRa-El," declared the Norfolk Journal and Guide in 1924, "as the Lord appears to make an opening for them where none appeared to exist." 68

\section{AfRICAN ZIONISM}

Garvey's philosophy of racial loyalty expressed in the School of African Philosophy as well as in his other speeches and writings, was earlier influenced by the Zionist movement. At the Fourth UNIA International Convention in New York in August 1924, for example, a reporter for a Hebrew Zionist newspaper was heard to exclaim across the press table, "This is Negro Zionism." 69 The Dahomean protonationalist Kojo Tovalou-Houénou declared at the same convention that "your

68. quoted in $N W$, 5 July 1924.

69. Daily Worker, I8 August 1924. 
association, Mr. President $\ldots$ is the Zionism of the Black Race." 70

Identification of Garveyism with Zionism is a theme that runs throughout commentaries on the Garvey phenomenon. In a November 1922 interview Claude McKay stated that the Garvey "movement has all the characteristic features of the Jewish Zionists." 7 The same ideological identification persisted after World War II. In the classic statement of the theory and practice of postwar pan-African liberation, PanAfricanism or Communism, George Padmore addresses the prehistory of the movement and describes the phenomenon of what he defines as "Black Zionism or Garveyism."72 Amy Jacques Garvey also described Garveyism in her 1963 memoir as "Black Zionism."73

The political parallels between Garveyism and Zionism were remarkable. As irredentist phenomena, the twin movements were spawned in significant ways by territorial and diplomatic developments during World War I and by the perfervid debate surrounding the settlement of the nationalities question and the issue of national self-determination, matters that were important parts of the protracted peace negotiations. The ground swell of feeling on the part of blacks toward Africa and of Jews toward Palestine occurred within the same twelve months following the Armistice, the period that many historians believe registered the greatest change in attitudes of Jews and persons of African descent toward the question of national independence.

When interviewed by Michael Gold in August 1920, Garvey informed Gold, "Many white men have tried to uplift them [the Negroes], but the only way is for the $[\mathrm{N}]$ egroes to have a nation of their own, like the Jews, that will command the respect of the world with its achieve-

70. Les Continents, is October 1924.

71. "The Race Question in America," Izvestia, I8 November 1922.

72. George Padmore, Pan-Africanism or Communism (1955; reprint, Garden City, N.Y.: Doubleday-Anchor, 1972), pp. 65-82.

73. Garvey and Garveyism, pp. 252, 267. 
ments."74 The men of the American volunteer Jewish Legion-the first contingent of which was raised in New York in February 1918-became identified as a kind of Jewish national guard for Palestine, while the men of Garvey's uniformed Universal African Legion (UAL), organized the following year, symbolized the armed detachment of African liberation. At Garvey's mail-fraud trial the former UAL head Emmett L. Gaines was asked by the government prosecutor whether the UNIA had a military branch. He answered, "It has a uniform rank ... like the Masons and Odd Fellows and any other organization." To elucidate the character of his African legion, Garvey then interjected the simple declaration-"Zionists." "'s

In the case of both the Garvey and the Zionist movements, the center of political organization was the United States, specifically New York. Garvey launched a series of construction loans in 1920 that were analogous to the Palestine Restoration Fund promoted by the Zionist Organization of America for the avowed of purpose developing the "Jewish commonwealth of Palestine." 76 The various reconstruction funds that formed so intrinsic a feature of the organizing efforts of both movements were a reflection of their shared concepts of exodus and preparation. The Negro World of 8 August 1922, in providing a summary of one of Garvey's speeches, reported that Garvey asked his audience "if the Jews could have Palestine, why not the Negroes another Palestine in Africa?" The hoped-for African Palestine, as conceived by Garvey, was to have been Liberia. "We are asking the world for a fair chance to assist the people of Liberia in developing that country," he announced, "as the world is giving the Jew a fair chance to develop Palestine."77 Similarly, a

74. Michael Gold, "When Africa Awakes," New York World, 22 August 1920.

75. Marcus Garpey v. United States, no. 8317, Ct. App., 2d Cir., 2 February 1925, P. 1,699.

76. New York Times, 19 September 1919.

77. NW, 14 June 1924. 
proposal presented at the September 1919 Chicago convention of the Zionist Organization of America to transfer "all central Zionist Administrative Institutions and activities" to Palestine was mirrored by Garvey's announcement, in a Liberty Hall speech on 14 December 1919, that "after the [UNIA] convention to be held next August the headquarters of the association must be transferred to Monrovia, Liberia." 78

\section{Jewish Patronage}

During the peak years of the UNIA in the early twenties, a number of Jewish figures endorsed and contributed funds to Garvey's various schemes of African colonization. The Hungarian-born banker and philanthropist William C. Ritter of Brooklyn made a financial contribution to the UNIA's 1924 Liberian colonization program.79 Two Jewish physicians, Dr. L. A. Goldfine of Chicago and Dr. J. Gordon of New York, also gave warm endorsements to the movement. Gordon addressed the Third UNIA International Convention in August 1921 from the platform of Liberty Hall.80 Garvey's Jamaican patrons included Abraham Judah, the city engineer of Kingston, and Lewis Ashenheim, a leading luminary of the Jamaican bar. Whereas the former helped make possible Garvey's first English visit in 1913 and 1914-an undertaking that proved of immeasurable importance to Garvey's political and ideological orientation-the latter provided Garvey with critical legal defenses in Jamaica's courts after he was deported to the island from the United States. Garvey reciprocated by taking to the hustings in support of Ashenheim's candidacy in the 1935 election, the final election held in Jamaica under the old restricted franchise of crown colony rule. Garvey's support for Ashenheim proved unpopular with the electorate

78. Meyer W. Weisgal, "The Zionist Convention in Chicago," Maccabean, December 1919, p. 345; New York Times, 17 September 1919; National Archives, RG 165, file 10218-364-18-190X.

79. $N W, 7$ June 1924.

80. $N W, 3$ July and i6 September 1922. 
and occasioned a number of violent disturbances at meetings addressed by Garvey in Kingston. It also marked the end of twenty-five years of close political allegiance between Garvey and the opposing candidate and mayor of the city of Kingston, H. A. L. Simpson.

\section{Racial SUCCESS}

Garvey made frequent calls for blacks to emulate the economic successes and national ambition of Jews. "The Jew has something the Negro hasn't got," Garvey averred, "he has racial stamina." "We want to work out a plan like the Zionist so as to recover ourselves," Garvey advised readers of the December 1937 Black Man. ${ }^{82}$ In an editorial penned in mid-1936, at the outbreak of civil war between Arabs and Jews in Palestine, Garvey drew out the following moral for blacks:

The Negro, primarily, like the Jew, needs money, but he also needs simultaneously a strong nationalism. Let the Negro couple the urge for money with that of nationalism, so that in another hundred years when he arrives he will not have the difficulty the Jew is now having in Palestine, but he will have a formidable and well-established nation to protect him anywhere he happens to find himself with his wealth. There is no better place than Africa, his original home. The Negroes of the world, therefore, should concentrate on making money and in using a part of it for helping to establish an independent nationalism in Africa. ${ }^{83}$

\section{ANTi-Semitism}

Yet even while Garvey supported Jews as positive socioeconomic and political role models, he was by no means

8I. $B M$ I, no. 9 (August-September 1935): ro.

82. $B M$ 2, no. 9 (December 1937): 13.

83. $B M$ 2, no. 2 (July-August 1936): 3. 
free from the anti-Semitism of his times. He became increasingly anti-Semitic in his rhetoric following conviction on mail fraud charges in 1923, when he became convinced that Jewish and Catholic jurors and Judge Julian Mack, a leading Zionist and former head of the Zionist Organization of America, had been biased in the hearing of the case because of their political objections to his meeting with the acting imperial wizard of the Ku Klux Klan-an avowedly anti-Semitic and antiCatholic organization-in 1922. "When they wanted to get me," Garvey informed the Afro-American journalist Joel A. Rogers in 1928, "they had a Jewish judge try me, and a Jewish prosecutor. I would have been freed but two Jews on the jury held out against me ten hours and succeeded in convicting me, whereupon the Jewish judge gave me the maximum penalty." 84

This bitterness continued to pervade his thinking, and tainted the positive view of Jews he upheld earlier in his career. By the mid-1930s racist suspicion of the motivation of Jews was mixed with a more positive identification with Jews as an oppressed minority, so that Garvey frequently made statements about Jewish solidarity that were contradictory.

Garvey was a propagator of the anti-Semitic rhetoric common in the political era epitomized by the formation of the Rome-Berlin Axis in October 1936. He identified with the rise of both Hitler and Mussolini from lower-class status, and admired the power manifested in their nationalistic brand of leadership. He praised both men in the early thirties as self-made leaders who had restored their nations' pride, and used the resurgence of Italy and Germany as an example to blacks for the possible regeneration of Africa. He admired in particular the remarkable ideological stamp the fascist leaders had succeeded in imprinting on the world. "In politics as in everything else," he declared, "movements of any kind [once] established, when centralized by leading characters generally leave their impression, and so Hitler, Mussolini, Stalin and

84. Philadelphia Tribune, 27 September 1928. 
the Japanese political leaders are leaving on humanity at large an indelible mark of their political disposition. 85 This admiration was tinged with jealousy over the spectacular impact of the fascist movement. In 1937 he went so far as to claim in a London interview with Joel A. Rogers that, as Rogers reported,

. . his Fascism preceded that of Mussolini and Hitler. "We were the first Fascists," [Garvey] said, "when we had 100,000 disciplined men, and were training children, Mussolini was still an unknown. Mussolini copied our Fascism." 86

Later the same year he declared that the "UNIA was before Mussolini and Hitler ever were heard of. Mussolini and Hitler copied the programme of the UNIA-aggressive nationalism for the black man in Africa." ${ }^{287}$

His naive identification with fascism in the mid-thirties merged readily with the unfortunate anti-Semitic beliefs he had been voicing since the mid-twenties. In his lessons for the School of African Philosophy-which were first delivered when the events of the past few years had brought Nazi policies of racial discrimination and oppression to the attention of the world-Garvey cautioned against relying on Jews, stating that the very racial solidarity he admired made Jews loyal only to themselves and not to other racial groups. These distasteful comments mark the development of antiSemitism within the black community in the United States, reflecting the tension that had developed in urban areas, in the course of the previous twenty years, between blacks who had migrated from the South or the Caribbean in the World

85. $B M_{3}$, no. Io (July 1938): 3 ; see also $B M$ I, no. I (December 1933): 23 ; and $B M 2$, no. 3 (September-October 1936): 2.

86. Joel A. Rogers, "Marcus Garvey," in Negroes of New York series, New York Writers Program, 1939, Schomburg Center for Research in Black Culture, New York.

87. $B M 2$, no. 8 (December 1937): 12. 
War I era and Jewish immigrants already established in the cities. Black perceptions of Jews were influenced by personal resentment of Jewish landlords and shopkeepers, on whom many blacks depended for housing and consumer goods. Jews, in turn, were influenced by the larger atmosphere of racial prejudice against blacks and prevailing patterns of residential segregation. This economic tension and cultural dissonance between Jews and blacks in areas where the UNIA was strong made blacks receptive toward anti-Semitic theories of international financial conspiracy.

These racist theories, popular in the early twenties, were propagated by such widely distributed organs as Henry Ford's Dearborn Independent and The International Jew. Garvey admired Ford as a self-made captain of industry, and was undoubtedly familiar with the anti-Semitic leanings of the Ford publications. Garvey also subscribed to the notorious Protocols of the Elders of Zion, which went through six editions in the United States between 1920 and 1922 . He told Joel A. Rogers in the course of a 1928 interview in England that "the Elders of Zion teach that a harm done by a Jew to a Gentile is no harm at all, and the Negro is a Gentile." 88 Garvey apparently accepted the theory-widely popular in the twenties and propagated by Ford's Dearborn Independent reporters and the Protocols-about the existence of a Jewish-capitalist-Bolshevik conspiracy. Garvey details the same conspiracy theory in his otherwise sympathetic editorials criticizing Nazi persecution of Jews. "Hitler is only making a fool of himself," Garvey argued in publicly denouncing Hitler's attacks upon Jews, declaring further:

Sooner or later the Jews will destroy Germany as they destroyed Russia. They did not so much destroy Russia from within as from without, and Hitler is driving the Jews to a more perfect organization from without Germany. Jewish finance is a powerful world factor. It 
can destroy men, organizations and nations. When the Jewish capitalists get together they will strike back at Germany and the fire of Communism will be lighted and Hitler and his gang will disappear as they have disappeared in Russia ... If Hitler will not act sensibly then Germany must pay the price as Russia did. ${ }^{89}$

Two years before, when Hitler rose to power in Germany, Garvey wrote of the ability of the Jews to ruin Germany financially. "The Jews are a powerful minority group," assayed Garvey, "and although they may be at a disadvantage in Germany, they can so react upon things German as to make the Germans, and particularly Hitler and the Nazis, rue the day they ever started the persecution. $\$ 0$

While Garvey promulgated prejudicial theories about Jewish culture in the lessons from the School of African Philosophy and elsewhere, he also expressed contrary views, at times harshly criticizing racial discrimination against Jews. In 1933 he directly linked the Jewish reputation for business acumen with German anti-Semitism. He strongly denounced discrimination against Jews as a minority group and ascribed anti-Jewish prejudice to racism motivated by jealousy of Jewish economic success. "The Jewish race is a noble one," he wrote in a 28 March 1933 New Jamaican editorial, and "the Jew is only persecuted because he has certain qualities of progress that other people have not learnt." He then drew a direct analogy between the persecution of Jews and the prejudice directed against blacks in the United States, and strongly denounced Nazi racial intolerance.9I $\mathrm{He}$ specifically denounced Hitler's and Mussolini's designs on African colonies, and linked Nazi prejudice against blacks with the persecution of Jews, describing both as racist policies that presented dangerous ramifications for world affairs.92

89. "Hitler and the Jews," $B M$ I, no. 8 (July 1935): 9.

90. New Jamaican, I April 1933.

91. see also New Jamaican, I April 1933.

92. $B M$ I, no. 7 (June 1935): 8; I, no. I2 (March 1936): I-3; 3, no. 9 (March 1938): I-2; 3, no. II (November 1938): I-2; 4, no. I (February 1939): I-2. 


\section{Dissemination OF THE LESSONS}

Garvey's School of African Philosophy was advertised in the Black Man throughout 1938, and in February 1939 Garvey announced that several more students had completed the lessons. In May 1939 a second session of the school was taught by Garvey at the Beaumont Crescent headquarters in London, and in June he released a new list of graduates, most of whom were from the United States. African graduates included Mr. J. O. Nwanolue, Onitsha, Nigeria; Mr. D. S. Musoke, Kampala, Uganda; and Mr. H. Illitintro, Cape Province, South Africa. African interest in the school did not go unnoticed by colonial authorities. On 22 June 1939 an intelligence report was sent to the chief secretary in Nairobi, Kenya, by the provincial commissioner of Nyanza province, reporting that collections were being taken up in North Kavirondo, Kenya, to pay for Garvey's correspondence course. 93

In the years immediately following Garvey's death the correspondence lessons from the School of African Philosophy continued to be circulated. Charles James of Philadelphia and James Stewart of Cleveland, both graduates of the original 1937 session in Toronto, continued to offer the course to applicants by mail. Later, William Sherrill offered the course to students through advertisements in the Philadelphia Garvey's Voice in the 1950s, and Clifford Barnes, commissioner of Louisiana, served as examiner for those students who subscribed to the correspondence course through Stewart's wing of the movement in the late ro4os.

\section{The Legacy}

The circumstances of Garvey's life and the lessons he taught his followers reflect the popular intellectual and political currents of his times, revised to the service of the revival of black consciousness. His life remains a testimony to his

93. Kenya National Archives, "Nyanza Province Intelligence Reports, 1939-1942," PC/NZA 4/5/3. 
spectacular ability to capture the popular imagination and move people to a new outlook. "After all discount is made," declared a contemporary, "after all the tinsel is brushed away, the fact remains that the grandiose schemes of Marcus Garvey gave to the race a consciousness such as it had never possessed before." 94

Marcus Garvey: Life and Lessons is a record, one hundred years after the birth of Garvey, of the travail of self-education among blacks. It was out of this tradition that the ideal of Africa's regeneration evolved. Garvey's positive contribution was to enrich its continuing legacy of race pride, selfmastery, and hope.

In her memoirs Amy Jacques Garvey wrote of a May 1928 symposium on Garvey at Howard University, where students debated the difference 'between 'The Man' and 'The Movement" that shared his name. The debaters agreed that Garveyism, as a philosophy of black pride and panAfricanism, was the solution to "the international problem of the Negro." They also agreed that "Garvey's philosophy was distinguished from the man Garvey" and stressed the timelessness and universality of his legacy. "Garvey was temporal," they noted, "but Garveyism was eternal."xs

What's in a name? As anyone familiar with the AfroAmerican folktale tradition knows, the answer to the question comes in the telling of the tale.

The Editors

94. Benjamin Brawley, "The Negro Literary Renaissance," Southern Workman, 56 (April 1927): 177.

95. Garvey and Garpeyism, pp. 190-191. 